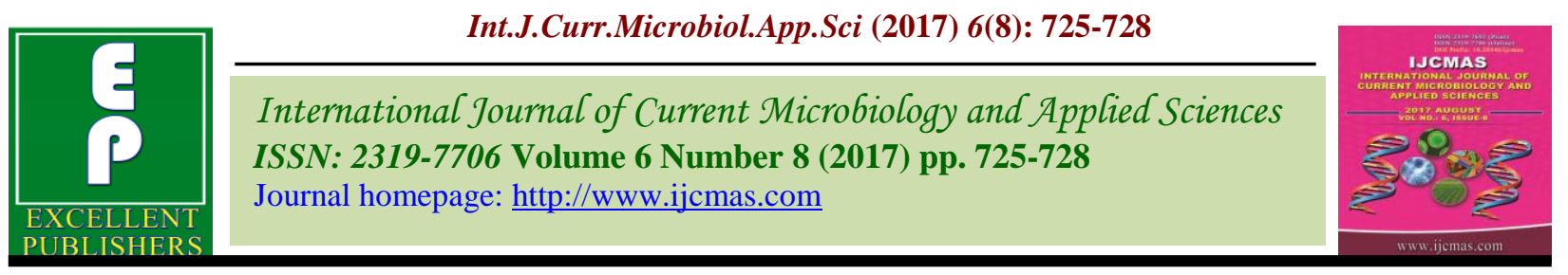

Original Research Article

https://doi.org/10.20546/ijcmas.2017.608.092

\title{
Effect of Fertilizer Based on Soil Testing for Better Production of Maize (Zea mays L.) in South Rajasthan, India
}

\author{
Ratan Lal Solanki $^{*}$, K.C. Naagar ${ }^{2}$ and S.K. Agarwal ${ }^{1}$ \\ ${ }^{1} \mathrm{KVK}$, Chittorgarh, Rajasthan, India \\ ${ }^{2}$ KVK Bhilwara, Rajaasthan, India
}

*Corresponding author

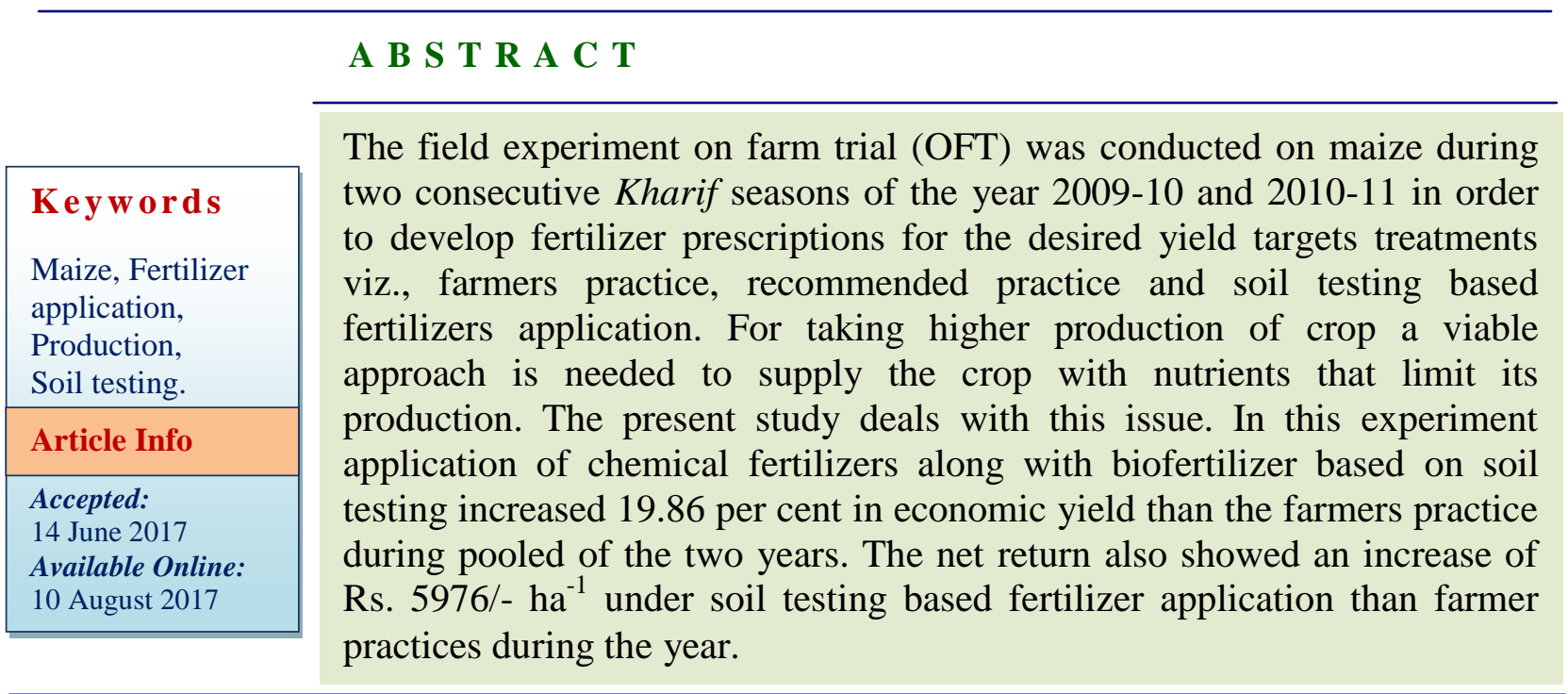

\section{Introduction}

Maize (Zea mays L.) is a major crop of Chittorgarh district in the Rajasthan. It is the basic important stable food of the mass consumption of Mewar area of Rajasthan. One of the major constraints of traditional farming is low productivity due to nonadoption of recommendation fertilizer application specially integrated nutrient management on soil test based. In Rajasthan it is grown on 1.0 million ha area with production $1.21 \mathrm{~m}$ ton and productivity of $1374 \mathrm{~kg} \mathrm{ha}^{-1}$ (Solanki et al., 2014) Agriculture is the main stay of life in district Chittorgarh of Rajasthan with an average gross cropped area of 118320 ha.
The district has a Sub Humid Southern Plains humid climate with average temperature of the district varies from $30-45^{\circ} \mathrm{C}$ in summer and $5-25^{\circ} \mathrm{C}$ in winter. Maximum yield potential of maize can be realized by adopting new and high yielding maize hybrids is associated with balance nutrient and consequently its availability in the soil. Fertilizer may affect the vegetative and reproductive growth resulting decline in seed maize yield due to Imbalance use.

Soil testing is a scientific technique used for assessing external nutrient need of crops to achieve profitable response. It provides 
current qualitative information on the nutrient and the nutrient supplying capacity of soil. It is the basis for making scientifically sound and management decision about the requirement of specific kind of fertilizers and soil amendments. In general, a simple soil test determines the $\mathrm{EC}, \mathrm{pH}$, organic carbon, phosphorus and potassium status of soil. Based on the estimated value, soils are categorized into two classes, viz., low and medium with respect to a particular nutrient.

Indiscriminate use of fertilizers in maize crop tilting mostly towards nitrogenous, $\mathrm{P} \& \mathrm{~K}$ fertilizers becomes a major threat to sustainable farming. Under such circumstances, nitrogen is simply used as a shovel to mine the other nutrients from soil and deteriorate its productive quality. Higher nitrogen application may be able to raise the yield upto a certain level but it removes 2 to 5 times more phosphorus, potassium and sulphur from soil than the normal limit.

The specific yield equation based on soil health besides ensuring sustainable crop production also steers the farmers towards economic use of costly fertilizer inputs depending on their financial status and prevailing market price of the crop under consideration (Bera et al., 2006).

The continuous over mining of these nutrients without adequate external supply leads to deterioration of inherent fertility status of soil and fails to produce the desired yield. The situation is much critical under maize production system as the amount of nutrient removed by maize is quite high.

In this context, use of fertilizers based on soil testing might be able to play a vital role in ensuring balanced nutrition to crop and also preventing wasteful expenditure on the use of costly mineral fertilizers (Benipal et al., 2001).

\section{Materials and Methods}

An on- farm testing (OFT) was conducted at the locations in Mangodada, taluka of Chittorgarh district of Rajasthan state during 2009-10 and 2010-11. Maize cv. PHEM-2 was grown under the irrigated conditions. Soils of the experimental sites were testes and rated as per the data given in table 1. in general the soils were neutral in reaction. Organic carbon content was found low in all the locations. Available phosphorus under medium rating and available potassium status of the soil was estimated as medium. In all the locations the availability of phosphorus and potassium were low and medium, respectively.

Generally farmers were utilizer more NPK fertilizers than recommendation, which resulted into high cost of cultivation and also affected the soil health. Therefore the treatments were finalized based on the compared in these trials in order to check the performance of exiting production practices with the soil testing based fertilizer application technique. The details of the treatment are given in table 2.

\section{Results and Discussion}

The results presented in table 3 indicated that maize yields were influenced due to different treatments. The increasing trend in yield was observed under different treatment. Treatment $\mathrm{T}_{3}$ recorded higher yield of maize $(36.58 \mathrm{q}$ ha ${ }^{1}$ ) as compared to treatment $\mathrm{T}_{2}$ and $\mathrm{T}_{1}$.

The same trend of results is also found by Kodmelwar et al., (1979) who reported that the use of non-symbiotic nitrogen fixing Azotobacter seed inoculation increased crop yields to the tune of 26 per cent in wheat in different locations. Similarly, Verma and Bhattacharya (1990) also observed increased in yield of wheat and maize with the 
application of organic manure in combination with be due to adequate and correct supply of nutrients exhibited a positive impact on the economic yield further, it was observed that farmers practice $\left(T_{1}\right)$ recorded lower yield than that of recorded under exiting recommended practices (RDF). Kalaichelvi and Chinnusamy (2005) also fond increment in yield attributes of maize with application of 100 per cent STCR recommended level rather than 75 and 50 per cent STCR recommended level. Soil testing based fertilizer application $\left(\mathrm{T}_{3}\right)$ recorded higher yield to the tune of 7.94 and 20.52 per cent, over treatment $T_{2}$ and $T_{1}$, respectively. With regards to economics, again $\mathrm{T}_{3}$ treatment recorded maximum gross return (Rs. 43896 ha $^{-1}$ ), net return (Rs. 21296 $\mathrm{ha}^{-1}$ ) and $\mathrm{B}$ : C ratio (1.94) as compared to treatment $T_{1}$ and $T_{2}$.

Table.1 Soil nutrient of selected location (Average)

\begin{tabular}{|l|c|c|}
\hline Parameters & Result & Category \\
\hline $\mathrm{pH}$ & 7.6 & Normal \\
\hline Electrical Conductivity $\left(\mathrm{dSm}^{-1}\right)$ & 0.38 & Normal \\
\hline Available $\mathrm{P}\left(\mathrm{Kg} \mathrm{ha}^{-1}\right)$ & 16.0 & Medium \\
\hline Available $\mathrm{K}\left(\mathrm{kg} \mathrm{ha}^{-1}\right)$ & 188.0 & Medium \\
\hline Organic carbon $(\%)$ & 0.30 & Low \\
\hline
\end{tabular}

Table. 2 Treatment details

\begin{tabular}{|l|l|}
\hline Treatments & Treatment details \\
\hline $\mathrm{T}_{1}$ Farmer's Practices & Farmer's practices $\left(90 \mathrm{~kg} \mathrm{~N}+30 \mathrm{~kg} \mathrm{P}_{2} \mathrm{O}_{5} \mathrm{ha}^{-1}\right)$ \\
\hline $\mathrm{T}_{2}$ Recommended Practices (RDF) & $90 \mathrm{~kg} \mathrm{~N}+30 \mathrm{~kg} \mathrm{P}_{2} \mathrm{O}_{5}+30 \mathrm{~kg} \mathrm{~K}_{2} \mathrm{O} \mathrm{ha}^{-1}$ \\
\hline $\mathrm{T}_{3}$ Soil testing based fertilizers application & $\begin{array}{l}100 \mathrm{~kg} \mathrm{~N}+40 \mathrm{~kg} \mathrm{P}_{2} \mathrm{O}_{5}+30 \mathrm{~kg} \mathrm{~K}_{2} \mathrm{O} \mathrm{ha}^{-1}+ \\
\text { Azotobactor \& PSB culture as seed treatment }\end{array}$ \\
\hline
\end{tabular}

Table.3 Yield and economics as influence by different treatments (Pooled of two years)

\begin{tabular}{|l|l|l|l|l|l|}
\hline \multicolumn{9}{|c|}{} & $\begin{array}{l}\text { Maize Yield } \\
\mathrm{q} \mathrm{h}^{-1}\end{array}$ & $\begin{array}{l}\text { Cost of } \\
\text { Cultivation Rs }\end{array}$ & $\begin{array}{l}\text { Gross Return } \\
\text { Rs }\end{array}$ & $\begin{array}{l}\text { Net Returns } \\
\text { (Rs) }\end{array}$ & B:C Ratio \\
\hline $\begin{array}{l}\mathrm{T}_{1} \text { Farmer's } \\
\text { Practices }\end{array}$ & 30.35 & 21100.00 & 36420.00 & 15320.00 & 1.72 \\
\hline $\begin{array}{l}\mathrm{T}_{2} \\
\begin{array}{l}\text { Recommended } \\
\text { Practices }\end{array}\end{array}$ & 33.88 & 21950.00 & 40656.00 & 18706.00 & 1.85 \\
\hline $\begin{array}{l}\mathrm{T}_{3} \text { Soil } \\
\begin{array}{l}\text { Testing based } \\
\text { fertilizers } \\
\text { application }\end{array}\end{array}$ & 36.58 & 22600.00 & 43896.00 & 21296.00 & 1.94 \\
\hline
\end{tabular}


Conduct refinement trial on effect of fertilizers on the bases of soil testing possibly increased the net return by Rs. 5976/- ha $^{-1}$. Fertilizer is the key factor to enhance productivity.

However, without efficient management of this costliest input, it may reduce the farmer's profitability as well as also adversely affect the soil quality. Several well established soil testing laboratories are operating in the state under various organizations.

This facility can be affectively utilized with a systematic approach for location specific fertilizer recommendation.

\section{References}

Benipal, S.K., Dhillon, N.S. and Brar, B.S. (2001). Soil test based fertilizer application necessary for better crop yields. Indian Farm, 51(8).

Bera, R., Seal, A., Bhattacharyya, P., Das, T.H., Sarkar, D. and Kangjoo, K. (2006). Targeted yield concept and a framework of fertilizer recommendation in irrigation rice domains of subtropical India. J. Zhejiang Univ. Sci., 7 (12): 963-968.

Kalaichelvi, K. and Chinnusamy, C. (2005). Productivity of cotton-black gram cropping system as influenced by STCR based fertilizer nutrients and potassium humate. Annuals Agril. Res., 26(1): 7579.

Kodmelwar et al., (1979). Response of wheat to Azotobacter, Micro nutrients and seed fungicide in field condition. Food Farm. \& Agric., II (2).

Solanki, R.L., Rathore, R.S., Dhakar, S.D. and Kanojia, Y. (2014). Yield gap analysis of integrated nutrient management in maize through front line demonstration. International Journal of Plant Sciences, 9(2): 438-440.

Verma, L.N. and Bhattacharya, P. (1990). Role of biotechnology in supplying plant nutrients in the nineties. Fertilizer News, 35(12): 87-97

\section{How to cite this article:}

Ratan Lal Solanki, K.C. Naagar and S.K. Agarwal. 2017. Effect of Fertilizer Based on Soil Testing for Better Production of Maize (Zea mays L.) in South Rajasthan. Int.J.Curr.Microbiol.App.Sci. 6(8): 725-728. doi: https://doi.org/10.20546/ijcmas.2017.608.092 